\title{
Usability Evaluation Aplikasi Berbasis Website dengan Menggunakan Metode Importance Performance Analysis
}

\author{
Putra Fajar Alam ${ }^{\mathrm{a}^{*}}$, Sari Wulandari ${ }^{\mathrm{b}}$ \\ a Program Studi Sistem Informasi, Fakultas Rekayasa Industri, Universitas Telkom \\ ${ }^{\text {b }}$ Program Studi Teknik Industri, Fakultas Rekayasa Industri, Universitas Telkom \\ Naskah Diterima : 5 Desember 2019; Diterima Publikasi : 31 Juli 2020 \\ DOI: 10.21456/vol10iss1pp122-130
}

\begin{abstract}
The Ministry of Environment and Forestry provides an appeal to waste banks to use online systems in managing waste bank activities. The online system referred to is the online waste management system through the banksampah.id account. However, the level of activity of garbage banks in using the online system is relatively low (36.46\%). Besides, in 2019, the Bandung City DLH has used banksampah.id as an application in evaluating the performance of waste banks. Therefore, this study was conducted aiming to evaluate the level of usability of banksampah.id so that it can be known aspects of banksampah.id that need to be improved. Evaluation of usability level is carried out using the Importance Performance Analysis (IPA) method. The usability evaluation results show that there are 7 usability attributes in the "Concentrate Here" category, 10 usability attributes in the "Keep Up The Good Work" category, 8 usability attributes in the "Low Priority" category and 9 usability attributes in the "Possible Overkill" category. Improvements to usability banksampah.id focus on 7 attributes categorized as "Concentrate Here" namely (1) availability of procedures for the use of various applications, (2) procedures for using applications that have been available easily understood by users, (3) completeness of customer profile, (4) availability of up-to-date customer data, (5) speed in data processing, (6) availability of communication features between Garbage Banks, and (7) availability of communication features between Garbage Banks and collectors.
\end{abstract}

Keywords : Usability Evaluation; IPA; Waste Bank ; Online Waste Management System; Web Usability

\begin{abstract}
Abstrak
KLHK memberikan himbauan kepada bank sampah untuk menggunakan sistem online dalam pengelolaan aktivitas bank sampah. Sistem online yang dirujuk adalah sistem online manajemen sampah melalui akun banksampah.id. Namun, tingkat keaktifan bank sampah dalam penggunaan sistem online tersebut tergolong rendah (36,46\%). Selain itu, pada tahun 2019, DLH Kota Bandung telah menggunakan banksampah.id sebagai aplikasi dalam mengevaluasi kinerja bank sampah. Adapun tujuan penelitian ini adalah untuk mengevaluasi tingkat usability banksampah.id, sehingga dapat diketahui aspek-aspek pada banksampah.id yang perlu diperbaiki. Metode evaluasi usability banksampah.id yang digunakan adalah Importance Performance Analysis (IPA). Hasil evaluasi usability menunjukkan bahwa terdapat 7 atribut berkategori "Concentrate Here", 10 atribut usability berkategori "Keep Up The Good Work", 8 atribut usability berkategori "Low Priority" dan 9 atribut usability berkategori "Possible Overkill". Perbaikan usability banksampah.id berfokus pada 7 atribut berkategori "Concentrate Here" yaitu (1) ketersediaan tata cara penggunaan aplikasi yang bervariasi, (2) tata cara penggunaan aplikasi yang telah tersedia mudah dimengerti oleh pengguna, (3) kelengkapan informasi profil/identitas nasabah, (4) ketersediaan data nasabah yang up-to-date, (5) kecepatan dalam proses pengolahan data, (6) ketersediaan fitur komunikasi antar Bank Sampah, dan (7) ketersediaan fitur komunikasi Bank Sampah dengan pengepul.
\end{abstract}

Kata Kunci : Usability Evaluation; IPA; Bank Sampah; Sistem Online Manajemen Sampah; Web Usability

\section{Pendahuluan}

Kondisi masalah persam pahan di Indonesia sudah memasuki status darurat. Setiap harinya dihasilkan sebanyak 175.000 ton sampah atau setara dengan 64 juta ton sampah per tahun (Baqiroh, 2019). Sebagian besar sampah tersebut yaitu sebesar $66,39 \%$ sampah tertimbun di TPA, dan hanya 14\% sampah yang sudah terolah. Kementerian Lingkungan Hidup dan Kehutanan (KLHK) melalui Kebijakan dan Strategi Nasional Pengelolaan Sampah Rumah Tangga dan

*) Penulis korespondensi: putrafajaralam @ telkomuniversity.ac.id 
Sampah Sejenis Sampah Rumah Tangga (Jakstranas) memiliki target pengurangan sampah sebesar $30 \%$ pada tahun 2025 dan target penanganan sampah sebesar $70 \%$. Adapun pendekatan yang dinilai efektif dalam pengelolaan sampah adalah dengan menggunakan sistem pengelolaan sampah melalui Bank Sampah. Bank Sampah dinilai sebagai solusi yang tepat dalam menyelesaikan masalah mismanagement sampah yang dihadapi oleh local governments pada negara berkembang (Raharjo, Matsumoto, Ihsan, Rachman, \& Gustin, 2017).

Pengelolaan sampah melalui Bank Sampah pertama kali diterapkan di Indonesia oleh Bank Sampah Bantul Yogyakarta pada tahun 2008. Saat ini, Bank Sampah telah diterapkan secara luas di Indonesia. Jumlah total Bank Sampah keseluruhan yang berada di Indonesia saat ini adalah sebanyak 8.768 Bank Sampah. Data persebaran Bank Sampah Indonesia dapat dilihat pada Gambar 1. Berdasarkan data pada Gambar 1. tersebut, dapat diketahui bahwa Bank Sampah telah menyebar di seluruh Indonesia, dengan jumlah Bank Sampah terbanyak berada di Pulau Jawa (6.549), Sulawesi \& Maluku (740) dan Sumatera (652). Jumlah Bank Sampah tersebut diproyeksi akan semakin meningkat pada tahun - tahun berikutnya.

Tabel 1. Persebaran Jumlah Bank Sampah di Indonesia Tahun 2019

\begin{tabular}{cc}
\hline Nama Provinsi & Jumlah Bank Sampah \\
\hline Jawa & 6549 \\
Sulawesi \& Maluku & 740 \\
Sumatera & 652 \\
Kalimantan & 545 \\
Bali \& Nusa Tenggara & 180 \\
Papua & 102 \\
\hline
\end{tabular}

Pada akhir tahun 2018, diketahui bahwa Bank Sampah berkontribusi dalam pengurangan sampah nasional hingga 2,76\% (Salengke, 2019). Data tersebut menunjukkan bahwa keberadaan Bank Sampah berpotensi untuk menunjang pencapaian target pengurangan sampah nasional. Namun hingga kini, Bank Sampah masih menemukan beberapa kendala dalam hal pengelolaan aktivitas persampahan yang dilakukannya. Sebagian besar Bank Sampah dikelola secara sukarela oleh masyarakat sehingga kapasitas SDM sangat terbatas. Di sisi lain, Bank Sampah menjadi alternatif sumber pendapatan bagi sebagian warga kurang mampu dan dijadikan sebagai peluang lapangan pekerjaan sedangkan mayoritas Bank Sampah belum mandiri secara ekonomi. Oleh karenanya, aktivitas Bank Sampah perlu dilakukan secara efisien dan efektif sehingga dapat menjalankan perannya sebagai circular economy dengan baik yaitu mengonversi sampah menjadi bernilai ekonomis. Adapun omset per tahun yang diperoleh Bank Sampah dari tahun 2012 - 2018 dapat dilihat pada Gambar 2. Data tahun 2021 merupakan data forecasting atau perkiraan.
Tabel 2. Rata-rata jumlah omset Bank Sampah per tahun

\begin{tabular}{cc}
\hline Tahun & Omset Bank Sampah \\
\hline 2012 & $\operatorname{Rp~3,591,739}$ \\
2015 & $\operatorname{Rp~10,341,297}$ \\
2018 & $\operatorname{Rp~5,433,013}$ \\
2021 & $\operatorname{Rp~5,705,048}$ \\
\hline
\end{tabular}

Aktivitas pengelolaan sampah pada Bank Sampah dapat dilakukan secara efisien dan efektif melalui penerapan teknologi informasi. Direktorat Jenderal Pengelolaan Sampah, Limbah, dan Bahan Beracun Berbahaya (Ditjen PSLB3) Kementerian Lingkungan Hidup dan Kehutanan memberikan himbauan kepada bank sampah untuk menggunakan sistem online dalam pengelolaan aktivitas bank sampah (FORDA, 2015). Salah satu aplikasi yang dirancang dan dapat digunakan dalam pengelolaan serta manajemen kegiatan bank sampah adalah Sistem Online Manajemen Sampah (Smash.id). Smash.id mengintegrasikan tiga stakeholder masalah persampahan yaitu Bank Sampah dengan kanal sistem banksampah.id, masyarakat (nasabah bank sampah) dengan kanal sistem mySmash dan pemerintah (KLHK, DLH, BLH) dengan kanal sistem e-smash.

Berdasarkan data internal Smash.id, sepanjang tahun 2015 hingga tahun 2018, tingkat keaktifan bank sampah dalam penggunaan sistem online (banksampah.id) masih tergolong rendah yaitu $36,46 \%$. Oleh karenanya, pada bulan April 2019, Pemkot Bandung melalui Dinas Lingkungan Hidup dan Kebersihan (DLHK) Kota Bandung mengeluarkan surat edaran mengenai kewajiban penggunaan sistem online manajemen sampah (Smash.id pada kanal banksampah.id) pada Bank Sampah sebagai dasar evaluasi kinerja Bank Sampah tersebut. Namun, ditemukan bahwa banyak Bank Sampah yang merasa kesulitan dan enggan menggunakan sistem online tersebut. Oleh karena itu, penelitian ini dilakukan untuk mengevaluasi usability aplikasi banksampah.id. Evaluasi usability dilakukan dengan menggunakan metode Importance Performance Analysis (IPA). Teknik IPA pertama kali dikembangkan oleh Martilla dan James pada tahun 1977, dan kini metode tersebut telah digunakan secara luas pada disiplin yang berbeda-beda dikarenakan kesederhanaan dan efficacy dalam menunjukkan posisi dari berbagai macam aspek dalam format visualisasi yang menarik (Al Jahwari, Sirakaya-Turk, \& Altintas, 2016). IPA menghasilkan matriks yang dapat memungkinkan pengambil keputusan dan stakeholder mengilustrasikan aspek pelayanan yang paling penting menurut konsumen (Mcleay, Robson, $\&$ Yusoff, 2017). IPA telah digunakan sejak dahulu untuk memahami kebutuhan dan keinginan user, pemahaman tersebut digunakan sebagai bahan pertimbangan dalam mengembangkan strategi pemasaran (Phadermrod, Crowder, \& Wills, 2019). Pada penelitian ini, evaluasi usability dikaji dari aspek 
kinerja penggunaan banksampah.id pada sudut pandang user. Output atau hasil evaluasi tersebut digunakan sebagai bahan pertimbangan untuk mengembangkan dan memperbaiki usability banksampah.id.

\section{Kerangka Teori}

\subsection{Banksampah.id}

Banksampah.id merupakan aplikasi manajemen Bank Sampah berbasis website. Aplikasi ini dirilis pada awal tahun 2015. Jumlah Bank Sampah yang telah terhubung melalui aplikasi Banksampah.id ini adalah sebesar 4.600 Bank Sampah dari 34 Provinsi atau sebesar 57,24\% dari Bank Sampah di seluruh Indonesia. Sedangkan jumlah nasabah yang di daftarkan oleh Bank Sampah sebesar 21.776. Total transaksi digital yang terjadi berjumlah 80.235 transaksi.

\subsection{Website Quality \& Web Usability}

Website quality merupakan pengembangan dari konsep Service Quality (SERVQUAL) yang penggunaannya sudah umum dalam pengukuran kualitas jasa. Website quality secara general dapat didefinisikan sebagai tingkat conformance atau kesesuaian kualitas layanan website terhadap harapan stakeholder (Canziani \& Welsh, 2016). Selain itu, faktor utama yang menjadikan sebuah website memiliki aspek usability yang baik adalah perilaku atau kebiasaan user dalam menggunakan atau mengoperasikan website (Nielsen, 1994). Usability didefinisikan sebagai ukuran kualitas pengalaman berinteraksi pengguna dengan sebuah produk ataupun sistem. Produk atau sistem yang dimaksud bisa berbentuk Website, Aplikasi Perangkat Lunak (software application), teknologi mobile maupun perangkat yang dapat dioperasikan lainnya (Pearson, Pearson, \& Green, 2007). Penelitian ini membahas mengenai usability sebuah website yaitu ukuran kualitas pengalaman pengguna Website. Evaluasi kualitas sebuah website dengan mempertimbangkan penilaian user memberikan informasi observasi kualitatif dan data kuantitatif mengenai kinerja actual website (Carlos \& Rodrigues, 2012).

Pada Tabel 3 merupakan hasil rekapitulasi penelitian terdahulu mengenai penggunaan Variabel web quality dan web usability. Berdasarkan data penelitian terdahulu pada Tabel 3 dapat diketahui bahwa beberapa variabel usability seperti Navigation, Content, Security, Learnability, Web Design, Performancel Accessibility sudah umum digunakan oleh peneliti sebelumnya pada objek Aplikasi berbasis website. Oleh karena itu, variabel usability tersebut digunakan dalam penelitian ini. Adapun variabel communication pada penelitian Hasan (2014) digunakan dalam penelitian ini, namun dengan menggunakan istilah Interactivity yaitu mengenai kemampuan website untuk mengakomodasi komunikasi antar pengguna Website. Adapun penjelasan mengenai variabel usability yang digunakan dalam penelitian ini dijelaskan pada Tabel 4.

\subsection{Importance Performance Analysis}

Importance Performance Analysis telah dikembangkan dan digunakan secara meluas untuk memahami kepuasan pelanggan dan memberikan arahan dalam memprioritaskan strategi yang berdasar pada asumsi bahwa kepuasan adalah resultan dari preferensi (perceived importance) layanan dan penilaian relevan terhadap kinerja (Hua \& Chen, 2019). Selain itu, Rohayati, dkk (2018) menyatakan bahwa Importance Performance Analysis merupakan analysis tool yang digunakan untuk mengevaluasi kepuasan pelanggan dan strategi manajemen

Tabel 3. Rekapitulasi Variabel Website Quality dan atau Website Usability berdasarkan penelitian dahulu yang relevan

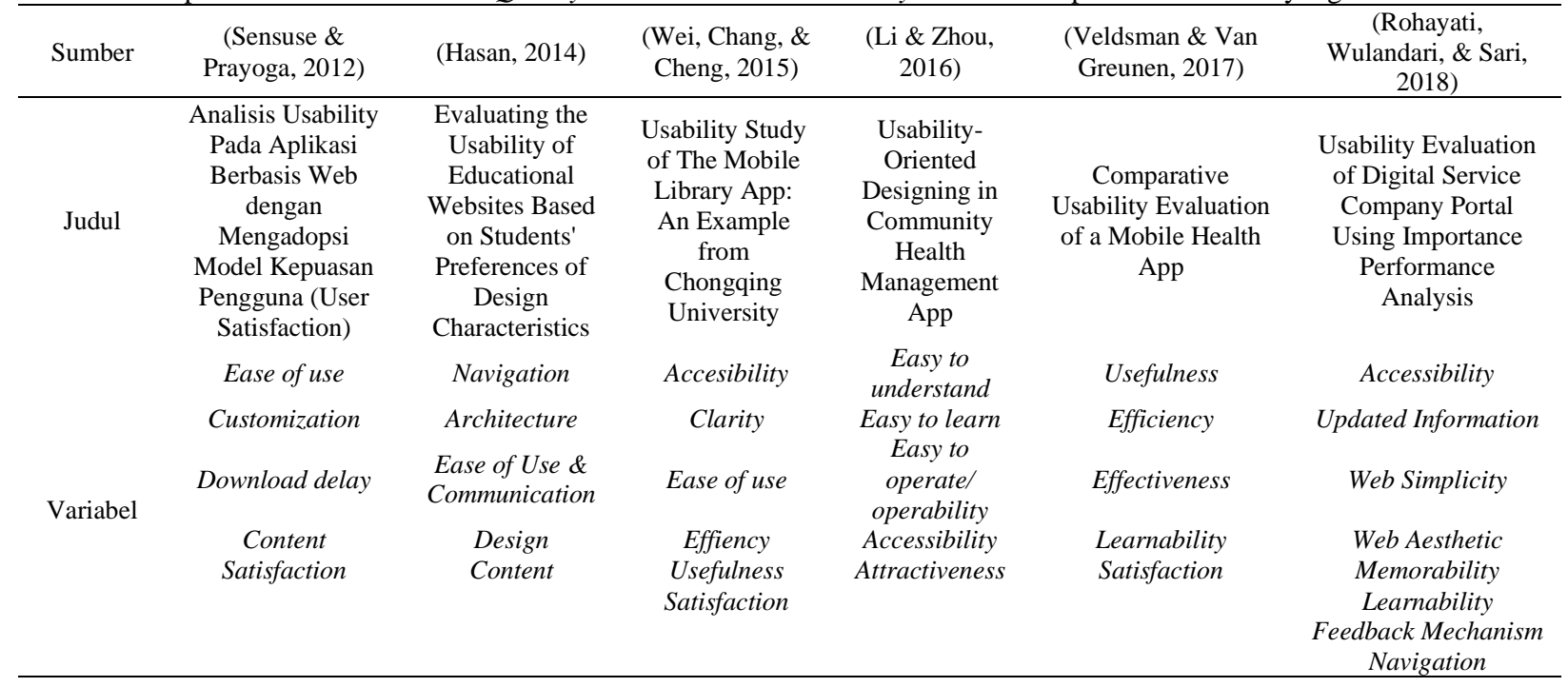


Tabel 4. Variabel Penelitian Website Quality

\begin{tabular}{|c|c|c|}
\hline No. & Variabel & Definisi \\
\hline 1. & Navigation & $\begin{array}{l}\text { Pengelolaan navigasi pada website } \\
\text { seperti tata letak pengaturan, urutan } \\
\text { halaman, dan layout website. }\end{array}$ \\
\hline 2. & Content & $\begin{array}{l}\text { Kualitas dan kesesuaian informasi serta } \\
\text { data pada website dengan kebutuhan } \\
\text { pengguna. }\end{array}$ \\
\hline 3. & Security & $\begin{array}{l}\text { Kemampuan website dalam menjaga } \\
\text { kemanan data akun user pada sistem } \\
\text { website. }\end{array}$ \\
\hline 4. & Learnability & $\begin{array}{l}\text { Kemudahan website untuk dipelajari dan } \\
\text { dimengerti mengenai cara } \\
\text { penggunaannya. }\end{array}$ \\
\hline 5. & Web Design & $\begin{array}{l}\text { Rancangan komponen yang berkaitan } \\
\text { dengan keindahan tampilan website, } \\
\text { fungsi dan variabel seperti warna, } \\
\text { ukuran, penggunaan logo/icon secara } \\
\text { keseluruhan. }\end{array}$ \\
\hline 6. & $\begin{array}{l}\text { Performance } \\
\text { (Accessibility) }\end{array}$ & $\begin{array}{l}\text { Kemampuan dan kecepatan website } \\
\text { dalam merespon perintah user dan } \\
\text { menjalankan fungsinya. }\end{array}$ \\
\hline 7. & Interactivity & $\begin{array}{lcr}\text { kemampuan sebuah website } & \text { dalam } \\
\text { menyediakan } & \text { fitur } & \text { untuk } \\
\text { mengakomodasi } & \text { komunikasi } & \text { antar } \\
\text { pengguna. } & & \end{array}$ \\
\hline
\end{tabular}

\subsection{Importance Performance Analysis}

Importance Performance Analysis telah dikembangkan dan digunakan secara meluas untuk memahami kepuasan pelanggan dan memberikan arahan dalam memprioritaskan strategi yang berdasar pada asumsi bahwa kepuasan adalah resultan dari preferensi (perceived importance) layanan dan penilaian relevan terhadap kinerja (Hua \& Chen, 2019). Selain itu, Rohayati, dkk (2018) menyatakan bahwa Importance Performance Analysis merupakan analysis tool yang digunakan untuk mengevaluasi kepuasan pelanggan dan strategi manajemen.

IPA memberikan visualisasi gap antara persepsi stakeholder akan tingkat kepentingan atribut dengan kinerja aktual perusahaan terhadap pengelolaan atribut tersebut (Boley, McGehee, \& Tom Hammett, 2017) yaitu melalui grafik visual yang menggambarkan rataan persepsi tingkat kepentingan dan hasil kinerja dari atribut. Visualisasi tersebut memudahkan pihak manajerial untuk mengetahui atribut manajemen yang perlu diperbaiki.

\section{Metode}

Pada penelitian ini metode yang digunakan adalah IPA (Importance Performance Analysis). Tahapan atau aspek yang krusial dalam metode IPA adalah menentukan nilai kepentingan dari setiap atribut yang dievaluasi (Bi, Liu, Fan, \& Zhang, 2019). Pendekatan dalam menentukan nilai kepentingan dalam metode IPA diklasifikasikan ke dalam dua kategori yaitu pendekatan self-stated dan pendekatan implicit (Taplin, 2012; Van Ittersum dkk., 2007 dalam Bi et al., 2019).

IPA merupakan teknis analitis visual yang menghasilkan dua Variabel grid yaitu importance dan performance. Grid (kuadran) tersebut dihasilkan berdasarkan sebuah proses yaitu (Martilla dan James, 1977 dalam Padlee, Reimers, Mokhlis, Anuar, \& Ahmad, 2019):

1. Mengidentifikasi atribut yang akan diukur

2. Memisahkan pengukuran nilai tingkat kepentingan (importance) dan tingkat kinerja (performance)

3. Posisikan sumbu vertical pada grid

4. Menganalisa importance-performance grid (kuadaran)

Teknik analitis ini dioperasikan berdasarkan hasil gap rataan (mean) antara importance dan performance. Setiap atribut tersebut kemudian akan dipetakan dalam 4 kuadran seperti pada Gambar 1 . Pada penelitian ini metode atau pendekatan yang digunakan untuk menentukan nilai kepentingan adalah pendekatan self-stated yaitu dengan menggunakan kuesioner. Kuesioner dalam penelitian ini mengukur atribut usability yang akan dievaluasi tingkat kepentingan dan kinerjanya. Langkah pertama dalam menyusun kuesioner adalah menentukan atribut usability dari setiap Variabel usability yang akan diukur (Padlee, Reimers, Mokhlis, Anuar, \& Ahmad, 2019). Atribut usability diperoleh dari hasil wawancara terhadap terhadap 10 bank sampah yang berada di kota/kabupaten Bandung. Hasil identifikasi atribut usability pada setiap variabel usability dapat dilihat pada Tabel 5.

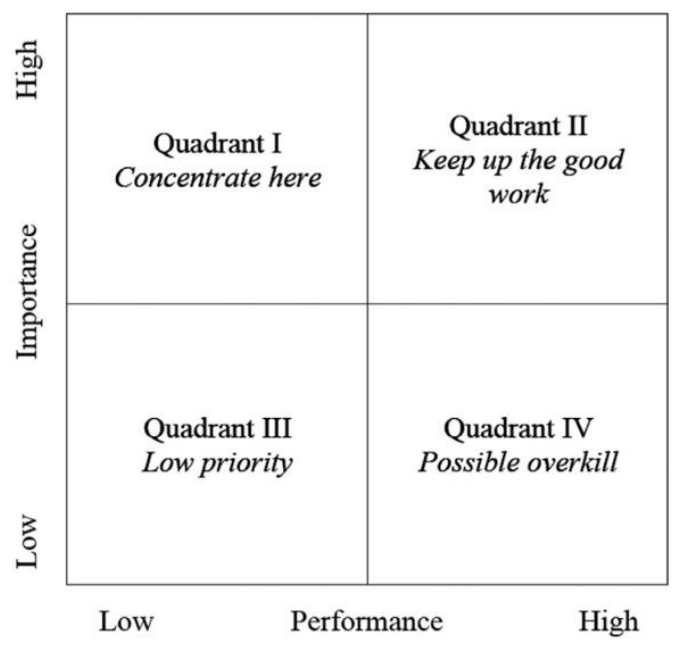

Gambar 1. Matriks Importance-Performance Analysis

Tabel 5. Atribut Usability Variabel Penelitian

\begin{tabular}{lll}
\hline Variabel & Atribut & Kode Atribut \\
\hline & $\begin{array}{l}\text { Kemudahan aplikasi dalam } \\
\text { penggunaannya ( } \text { user } \\
\text { friendly) }\end{array}$ & LEA1 \\
& $\begin{array}{l}\text { Kemudahan dalam } \\
\text { memahami aplikasi oleh }\end{array}$ & LEA2 \\
& $\begin{array}{l}\text { pengguna secara cepat } \\
\text { Tampilan menu yang tersedia } \\
\text { mudah dimengerti }\end{array}$ & LEA3 \\
& $\begin{array}{l}\text { Ketersediaan tata cara } \\
\text { penggunaan aplikasi yang } \\
\text { bervariasi (contoh : } \\
\text { gambar/foto, flow chart, } \\
\text { video) }\end{array}$ & \\
& LEA4
\end{tabular}




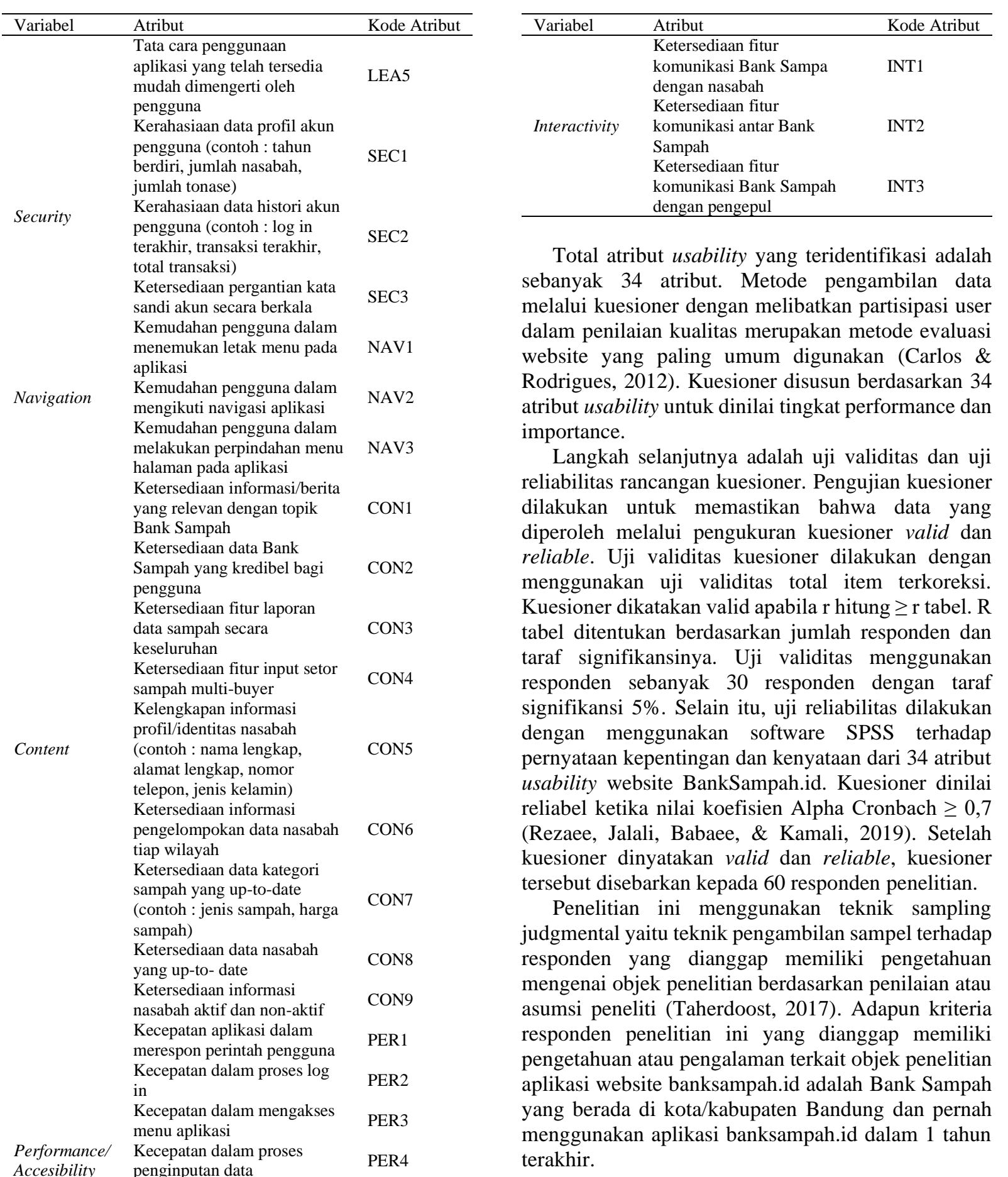

Kecepatan dalam proses pengolahan data

Ketersediaan data transaksi yang akurat

Ketersediaan akses

informasi/data pengepul

Tampilan menu tersusun

secara rapi

Kombinasi warna yang sesuai

Web Design $\quad$ Pengaturan ukuran huruf

dalam tampilan aplikasi

Tampilan aplikasi yang menarik
PER5

Total atribut usability yang teridentifikasi adalah out. Metode pengambilan data desioner dengan melibatkan partisipasi user website yang paling umum digunakan (Carlos \& Rodrigues, 2012). Kuesioner disusun berdasarkan 34 atribut usability untuk dinilai tingkat performance dan mportance. dilakukan untuk memastikan bahwa data yang diperoleh melalui pengukuran kuesioner valid dan tabel ditentukan berdasarkan jumlah responden dan taraf signifikansinya. Uji validitas menggunakan sesponden sebanyak 30 responden dengan taraf signifikansi 5\%. Selain itu, uji reliabilitas dilakukan reliabel ketika nilai koefisien Alpha Cronbach $\geq 0,7$ (Rezaee, Jalali, Babaee, \& Kamali, 2019). Setelah kuesioner dinyatakan valid dan reliable, kuesioner rsebut disebarkan kepada 60 responden penelitian.

Penelitian ini menggunakan teknik sampling judgmental yaitu teknik pengambilan sampel terhadap responden yang dianggap memiliki pengetahuan asumsi peneliti (Taherdoost, 2017). Adapun kriteria responden penelitian ini yang dianggap memiliki plikasi website banksampah.id adalah Bank Sampah yang berada di kota/kabupaten Bandung dan pernah terakhir.

\section{Hasil dan Pembahasan}

PER6

PER7

WEB1

WEB2

WEB3

WEB4
Langkah awal pengolahan data adalah pengujian alat ukur penelitian yaitu uji validitas dan reliabilitas kuesioner. Hasil keseluruhan uji validitas terhadap pernyataan importance dan performance pada Tabel 6 yang terdiri dari 34 atribut pengukuran memiliki nilai $r$ hitung $\geq r$ tabel. Nilai $r$ tabel yang digunakan pada uji validitas ini sebesar $0,361(\mathrm{n}=30$, taraf signifikansi $5 \%)$. Kuesioner dikatakan valid apabila $r$ hitung $\geq r$ tabel. $R$ 
Tabel 6. Hasil Uji Validitas (r hitung) Item Pernyataan

\begin{tabular}{|c|c|c|}
\hline Kode Atribut & $\begin{array}{l}\text { Pernyataan } \\
\text { Importance }\end{array}$ & $\begin{array}{l}\text { Pernyataan } \\
\text { Performance }\end{array}$ \\
\hline LEA1 & 0,885 & 0,483 \\
\hline LEA2 & 0,762 & 0,361 \\
\hline LEA3 & 0,715 & 0,565 \\
\hline LEA4 & 0,826 & 0,606 \\
\hline LEA5 & 0,751 & 0,648 \\
\hline SEC1 & 0,693 & 0,684 \\
\hline CON1 & 0,676 & 0,695 \\
\hline CON2 & 0,668 & 0,661 \\
\hline CON3 & 0,638 & 0,551 \\
\hline CON4 & 0,726 & 0,415 \\
\hline CON5 & 0,885 & 0,733 \\
\hline CON6 & 0,706 & 0,671 \\
\hline CON7 & 0,740 & 0,687 \\
\hline CON8 & 0,671 & 0,503 \\
\hline CON9 & 0,629 & 0,405 \\
\hline PER1 & 0,604 & 0,576 \\
\hline PER2 & 0,671 & 0,661 \\
\hline PER3 & 0,615 & 0,515 \\
\hline PER4 & 0,640 & 0,459 \\
\hline PER5 & 0,885 & 0,733 \\
\hline PER6 & 0,751 & 0,534 \\
\hline PER7 & 0,715 & 0,565 \\
\hline WEB1 & 0,809 & 0,551 \\
\hline WEB2 & 0,768 & 0,566 \\
\hline WEB3 & 0,783 & 0,389 \\
\hline WEB4 & 0,740 & 0,702 \\
\hline INT1 & 0,681 & 0,410 \\
\hline INT2 & 0,774 & 0,675 \\
\hline INT3 & 0,776 & 0,427 \\
\hline
\end{tabular}

Selain itu, hasil uji reliabilitas dapat dilihat pada Tabel 5, diketahui bahwa setiap pernyataan memiliki nilai koefisien Alpha Cronbach setiap pernyataan $\geq$ 0,7 . Berdasarkan hasil uji validitas dan reliabilitas, kuesioner dinyatakan valid dan reliabel sehingga data hasil pengukuran melalui kuesioner pun dapat dikatakan valid dan reliable.

Tabel 7. Hasil Uji Reliabilitas Pernyataan Kuesioner

\begin{tabular}{ccc}
\hline Pernyataan & $\begin{array}{c}\text { Nilai Koefisien } \\
\text { Alpha Cronbach }\end{array}$ & Keterangan \\
\hline Importance & 0,975 & Reliabel \\
Performance & 0,947 & Reliabel \\
\hline
\end{tabular}

Langkah selanjutnya adalah melakukan pengukuran gap antara tingkat kepentingan dengan tingkat kinerja (Rezaee, Jalali, Babaee, \& Kamali, 2019). Pendekatan IPA merupakan analisis GAP dengan membandingkan nilai performance (kinerja) dan importance (kepentingan) dari sebuah atribut. Kondisi dimana nilai kepentingan lebih tinggi daripada nilai kinerja mengindikasikan GAP yang negatif sedangkan kondisi sebaliknya yaitu kepentingan lebih rendah daripada nilai kinerja mengindikasikan GAP yang positif (Albayrak, 2015). Adapun rata-rata tingkat kepentingan atribut layanan secara keseluruhan adalah sebesar 3,34 sedangkan rata-rata tingkat kinerja atribut layanan secara keseluruhan adalah sebesar 3,44. Berdasarkan data rata-rata tingkat kepentingan dan kinerja tersebut dapat disimpulkan bahwa usability banksampah.id secara keseluruhan dapat dikatakan cukup baik. Hasil perhitungan Gap Rataan antara tingkat kepentingan dan tingkat kinerja dapat dilihat pada Tabel 8.
Tabel 8. Rata-rata nilai tingkat kinerja dan kepentingan

\begin{tabular}{|c|c|c|c|c|}
\hline \multirow[t]{2}{*}{ Variabel } & \multirow{2}{*}{$\begin{array}{c}\text { Kode } \\
\text { Atribut }\end{array}$} & \multicolumn{2}{|c|}{ Mean } & \multirow[t]{2}{*}{ Gap } \\
\hline & & Performance & Importance & \\
\hline \multirow[t]{5}{*}{ Learnability } & LEA1 & 3,60 & 3,50 & 0,10 \\
\hline & LEA2 & 3,73 & 3,52 & 0,22 \\
\hline & LEA3 & 3,23 & 3,27 & $-0,03$ \\
\hline & LEA4 & 3,10 & 3,62 & $-0,52$ \\
\hline & LEA5 & 3,27 & 3,45 & $-0,18$ \\
\hline \multirow[t]{3}{*}{ Security } & SEC1 & 3,43 & 3,53 & $-0,10$ \\
\hline & SEC2 & 3,53 & 3,53 & 0,00 \\
\hline & SEC3 & 3,07 & 3,43 & $-0,37$ \\
\hline \multirow[t]{3}{*}{ Navigation } & NAV1 & 3,50 & 3,28 & 0,22 \\
\hline & NAV2 & 3,37 & 3,43 & $-0,07$ \\
\hline & NAV3 & 3,40 & 3,50 & $-0,10$ \\
\hline \multirow[t]{9}{*}{ Content } & CON1 & 3,53 & 3,40 & 0,13 \\
\hline & $\mathrm{CON} 2$ & 3,47 & 3,42 & 0,05 \\
\hline & CON3 & 3,30 & 3,28 & 0,02 \\
\hline & CON4 & 3,77 & 3,38 & 0,38 \\
\hline & CON5 & 3,20 & 3,58 & $-0,38$ \\
\hline & CON6 & 3,37 & 3,30 & 0,07 \\
\hline & CON7 & 3,20 & 3,13 & 0,07 \\
\hline & CON8 & 3,13 & 3,52 & $-0,38$ \\
\hline & CON9 & 3,47 & 3,32 & 0,15 \\
\hline Performance & PER1 & 3,50 & 3,40 & 0,10 \\
\hline \multirow{6}{*}{ / Accesibility } & PER2 & 3,47 & 3,40 & 0,07 \\
\hline & PER3 & 3,17 & 3,37 & $-0,20$ \\
\hline & PER4 & 3,67 & 3,52 & 0,15 \\
\hline & PER5 & 3,20 & 3,57 & $-0,37$ \\
\hline & PER6 & 3,37 & 3,50 & $-0,13$ \\
\hline & PER7 & 3,23 & 3,33 & $-0,10$ \\
\hline \multirow[t]{4}{*}{ Web Design } & WEB1 & 3,63 & 3,48 & 0,15 \\
\hline & WEB2 & 3,27 & 3,38 & $-0,12$ \\
\hline & WEB3 & 3,40 & 3,55 & $-0,15$ \\
\hline & WEB4 & 3,53 & 3,58 & $-0,05$ \\
\hline \multirow[t]{3}{*}{ Interactivity } & INT1 & 2,87 & 3,30 & $-0,43$ \\
\hline & INT2 & 3,07 & 3,60 & $-0,53$ \\
\hline & INT3 & 3,10 & 3,55 & $-0,45$ \\
\hline
\end{tabular}

Berdasarkan data pada Tabel 8 dapat diketahui atribut layanan dengan nilai gap negatif. Nilai gap negatif menunjukkan kinerja atribut usability yang masih berada di bawah tingkat kepentingan. Gap negatif pada variabel Learnability diantaranya adalah LEA3, LEA4 dan LEA5. Gap negatif pada variabel Security diantaranya adalah SEC1 dan SEC3. Gap negatif pada variabel Navigation diantaranya adalah NAV2 dan NAV3. Gap negatif pada variabel Content diantaranya adalah CON5 dan CON8. Gap negatif pada variabel accessibility/performance diantaranya adalah PER3, PER5, PER6 dan PER7. Gap negatif pada variabel web design adalah WEB2, WEB3 dan WEB4 sedangkan semua atribut usability pada variabel Interactivity bernilai negatif.

Langkah selanjutnya adalah memetakan atribut usability menggunakan diagram cartesius sehingga dapat diketahui sebaran atribut usability berdasarkan 4 kuadran IPA (Padlee, Reimers, Mokhlis, Anuar, \& Ahmad, 2019). Hasil pemetaan atribut usability pada diagram IPA dapat dilihat pada Gambar 2. Boley, McGehee, \& Tom Hammett (2017) menyatakan bahwa atribut yang diprioritaskan dan menjadi fokus perbaikan pihak manajerial adalah atribut yang berada pada kuadaran I. Atribut usability yang berada pada kuadran I merupakan atribut dengan tingkat kepentingan-importance yang tinggi namun memberikan kinerja atau performance yang rendah 
sehingga atribut yang berada pada kuadran I mendapatkan prioritas untuk segera diperbaiki. Adapun atribut variabel Learnability yang berada pada kuadran I ("Concentrate Here") diantaranya adalah:

- LEA4: Ketersediaan tata cara penggunaan aplikasi yang bervariasi (contoh: gambar/foto, flow chart, video). Tata cara penggunaan aplikasi banksampah.id yang saat ini tersedia terbatas pada manual book saja. Ketersediaan tata cara penggunaan aplikasi (LEA4) sangat terbatas, oleh karena itu, diperlakukan penambahan variasi tata cara penggunaan aplikasi berupa gambar, flowchart ataupun video

- LEA5: Tata cara penggunaan aplikasi yang telah tersedia mudah dimengerti oleh pengguna. Manual book mengenai tata cara penggunaan aplikasi yang tersedia saat ini dinilai tidak mudah dimengerti (LEA5). Hal ini dikarenakan kecenderungan pengguna yang enggan menggunakan manual book sebagai panduan penggunaan. Pengguna lebih menyukai informasi tata cara penggunaan aplikasi yang atraktif dan mudah dipahami seperti video dan gambar.

Learnability merupakan variabel kualitas website yang menunjukan seberapa mudah user dapat mengoperasikan website serta seberapa mudah user mengingat cara penggunaan website (Veldsman \& Van Greunen, 2017). Selain itu, Rohayati dkk (2018), Veldsman dan Van Greunen (2017) serta Li dan Zhou (2016) dalam penelitiannya menunjukan bahwa variabel Learnability menjadi aspek penting dalam meningkatkan usability. Hasil penelitian tersebut sejalan dengan ouput penelitian ini yang menemukan bahwa atribut variabel Learnability masuk sebagai atribut yang diprioritaskan untuk diperbaiki.

Selain itu terdapat 2 atribut Content yang terkategori pada kuadaran I diantaranya adalah:

- CON5: Kelengkapan informasi profil/identitas nasabah (contoh: nama lengkap, alamat lengkap, nomor telepon, jenis kelamin). Saat ini, data identitas nasabah masih terbatas pada data yang bersifat umum seperti nama, email, nomor kontak, alamat, saldo dan tonase.

- CON8: Ketersediaan data nasabah yang up-todate. Beberapa kondisi yang menyebabkan atribut CON8 berada pada kuadran I adalah konektivitas internet yang tidak memadai pada lokasi bank sampah dan keterbatasan pada spesifikasi perangkat yang digunakan oleh bank sampah dalam melakukan proses input data.

Sensuse \& Prayoga (2012) dan Hasan (2014) dalam penelitian mengenai analisis dan evaluasi usability menggunakan variabel Content sebagai variabel kualitas usability website. Rohayati, dkk (2018) menggunakan variabel yang hamper serupa yaitu Updated Information. Pada ketida penelitian tersebut ditemukan bahwa Content dan Information menjadi variabel yang perlu diprioritaskan pengembangannya. Hal ini dikarenakan content dan information menjadi alasan utama user mengakses website tersebut. Hasil penelitian tersebut sejalan dengan ouput penelitian ini yaitu mengenai konten informasi yang perlu disesuaikan dengan kebutuhan user. Di sisi lain, hanya terdapat 1 atribut variabel performance yang berada pada kuadaran I yaitu PER5 mengenai kecepatan dalam proses pengolahan data. Dua atribut lainnya yang berada pada kuadaran I adalah atribut dari variabel Interactivity yaitu:

- INT2: Ketersediaan fitur komunikasi antar Bank Sampah

- INT3: Ketersediaan fitur komunikasi Bank Sampah dengan pengepul

Kedua atribut tersebut belum tersedia pada aplikasi BankSampah.id sedangkan kedua atribut usability tersebut merupakan atribut yang dianggap penting user aplikasi BankSampah.id. Sejalan dengan hasil penelitian yang dilakukan Hasan (2014) yang menunjukan bahwa variabel Communication yaitu kemampuan sebuah website untuk dapat mengakomodasi komunikasi antar user adalah hal penting yang perlu ada dalam sebuah website.

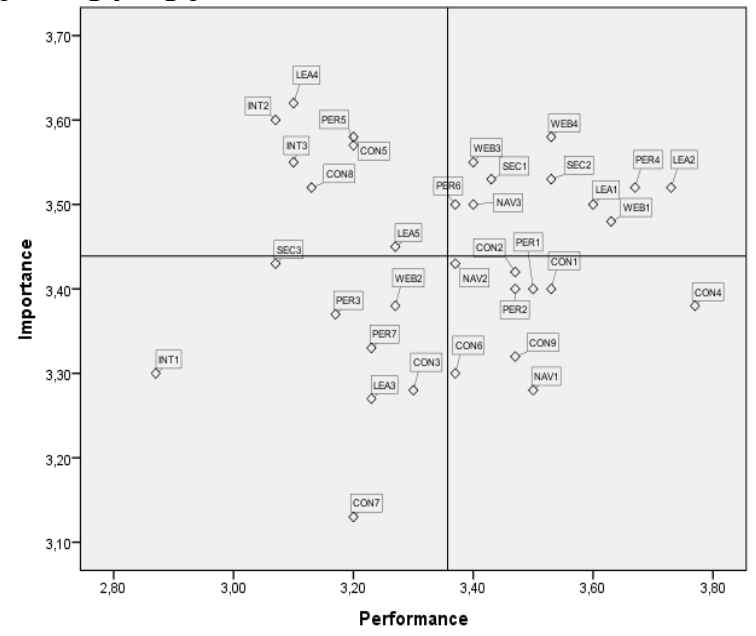

Gambar 2. Diagram IPA Web Usability BankSampah.id

Pada Gambar 2 juga dapat diketahui bahwa terdapat 10 atribut usability yang masuk ke dalam kuadran II. Atribut usability yang masuk ke dalam kuadran II merupakan atribut dengan tingkat kepentingan yang tinggi dengan tingkat kinerja yang tinggi pula. Oleh karena itu, atribut yang masuk dalam kuadran II perlu dipertahankan dikarenakan tingkat kinerja yang sudah sesuai dengan tingkat kepentingannya, sehingga tidak menjadi prioritas perbaikan (Boley et al., 2017). Berikut adalah atribut usability yang masuk ke dalam kuadran II (“Keep Up The Good Work”):

- LEA1: Kemudahan aplikasi dalam penggunaannya

- LEA2: Kemudahan dalam memahami aplikasi oleh pengguna secara cepat

- SEC1: Kerahasiaan data profil akun pengguna

- SEC2: Kerahasiaan data histori akun pengguna 
- NAV3: Kemudahan pengguna dalam melakukan perpindahan menu halaman pada aplikasi

- PER4: Kecepatan dalam proses penginputan data

- PER6: Ketersediaan data transaksi yang akurat

- WEB1: Tampilan menu tersusun secara rapi

- WEB3: Pengaturan ukuran huruf dalam tampilan aplikasi

- WEB4: Tampilan aplikasi yang menarik

Dua kuadaran lainnya yang tidak menjadi prioritas perbaikan adalah kuadran III dan IV. Terdapat 8 atribut usability yang masuk ke dalam kuadran III. Atribut usability yang masuk ke dalam kuadran III merupakan atribut dengan tingkat kepentingan dan tingkat kinerja yang rendah sehingga dikategorikan sebagai atribut "low priority" untuk diperbaiki (Phadermrod et al., 2019). Atribut usability berkategori "low priority" pada kuadran III diantaranya adalah:

- LEA3: Tampilan menu yang tersedia mudah dimengerti

- SEC3: Ketersediaan pergantian kata sandi akun secara berkala

- CON3: Ketersediaan fitur laporan data sampah secara keseluruhan

- CON7: Ketersediaan data kategori sampah yang up-to-date

- PER3: Kecepatan dalam mengakses menu aplikasi

- PER7: Ketersediaan akses informasi/data pengepul

- WEB2: Kombinasi warna yang sesuai

- INT1: Ketersediaan fitur komunikasi Bank Sampah dengan nasabah

Selain itu, terdapat 9 atribut usability yang termasuk ke dalam kuadran IV. Atribut yang masuk dalam kuadran IV merupakan atribut dengan tingkat kepentingan yang rendah namun memberikan tingkat kinerja yang tinggi sehingga atribut tersebut merupakan atribut yang dikembangkan secara tidak perlu atau disebut sebagai atribut yang "Possible overkill" (Mcleay et al., 2017). Adapun atribut yang termasuk ke dalam kategori "Possible overkill" diantaranya adalah:

- NAV1: Kemudahan pengguna dalam menemukan letak menu pada aplikasi

- NAV2: Kemudahan pengguna dalam mengikuti navigasi aplikasi

- CON1: Ketersediaan informasi/berita yang relevan dengan topik Bank Sampah

- CON2: Ketersediaan data Bank Sampah yang kredibel bagi pengguna

- CON4: Ketersediaan fitur input setor sampah multi-buyer

- CON6: Ketersediaan informasi pengelompokan data nasabah tiap wilayah

- CON9: Ketersediaan informasi nasabah aktif dan non-aktif

- PER1: Kecepatan aplikasi dalam merespon perintah pengguna

- PER2: Kecepatan dalam proses log in

\section{Kesimpulan}

Hasil web usability evaluation dengan menggunakan metode IPA menunjukkan 7 atribut usability pada kuadran I berkategori "Concentrate Here", terdapat 10 atribut usability pada kuadran II dengan kategori "Keep Up The Good Work", terdapat 8 atribut usability pada kuadran III dengan kategori "Low Priority" dan terdapat 9 atribut usability pada kuadran IV dengan kategori "Possible Overkill". Adapun fokus perbaikan usability website adalah pada atribut - atribut variabel yang berada pada kuadaran I ("Concentrate Here") yaitu atribut dengan tingkat importance tinggi namun tingkat performance rendah diantaranya adalah atribut LEA4, LEA5, CON5, PER5 CON8, INT2, dan INT3.

\section{Daftar Pustaka}

Al Jahwari, D. S., Sirakaya-Turk, E., Altintas, V., 2016. Evaluating communication competency of tour guides using a modified importanceperformance analysis (MIPA). International Journal of Contemporary Hospitality Management, 28(1), 195-218.

Baqiroh, N. F.A.B., 2019. Timbulan Sampah Nasional Capai 64 juta ton per Tahun.

Bi, J. W., Liu, Y., Fan, Z. P., Zhang, J., 2019. Wisdom of crowds: Conducting importance-performance analysis (IPA) through online reviews. Tourism Management, 70(September 2018), 460-478.

Boley, B. B., McGehee, N. G., Tom Hammett, A.L., 2017. Importance-performance analysis (IPA) of sustainable tourism initiatives: The resident perspective. Tourism Management, 58, 66-77.

Canziani, B. F., Welsh, D.H.B., 2016. Website quality for SME wineries : measurement insights.

Carlos, V.S., Rodrigues, R.G., 2012. Web site quality evaluation in Higher Education Institutions. Procedia Technology, 5, 273-282.

FORDA, 2015. Inovasi Pengembangan Bank Sampah Online.

Hasan, L., 2014. Evaluating the Usability of Educational Websites Based on Students' Preferences of Design Characteristics. International Arab Journal of E-Technology, 3(3), 178-193.

Hua, J., Chen, W.Y., 2019. Prioritizing urban rivers' ecosystem services: An importance-performance analysis. Cities, 94(August 2018), 11-23.

Li, X., Zhou, X.L., 2016. Usability-Oriented Designing in Community Health Management App. Conferences on Ubiquitous Intelligence \& Computing, Advanced and Trusted Computing, Scalable Computing and Communications, Cloud and Big Data Computing, Internet of People, and Smart World Congress, 855.

Mcleay, F., Robson, A., Yusoff, M., 2017. New applications for importance- performance analysis 
( IPA ) in higher education Understanding student satisfaction.

Nielsen, J., 1994. Guerrilla HCI: Using Discount Usability Engineering to Penetrate the Intimidation Barrier.

Padlee, S. F., Reimers, V., Mokhlis, S., Anuar, M. M., Ahmad, A., 2019. Keep up the good work in research universities: An importance-performance analysis. Australasian Marketing Journal, (xxxx).

Pearson, J.M., Pearson, A., Green, D., 2007. Determining the importance of key criteria in web usability. Management Research News, 30(11), 816-828.

Phadermrod, B., Crowder, R.M., Wills, G.B., 2019. Importance-Performance Analysis based SWOT analysis. International Journal of Information Management, 44, 194-203.

Raharjo, S., Matsumoto, T., Ihsan, T., Rachman, I., Gustin, L., 2017. Community-based solid waste bank program for municipal solid waste management improvement in Indonesia: a case study of Padang city. Journal of Material Cycles and Waste Management, 19(1), 201-212.

Rezaee, S., Jalali, M., Babaee, T., Kamali, M., 2019. Reliability and Concurrent Validity of a Culturally Adapted Persian Version of the Brace Questionnaire in Adolescents With Idiopathic Scoliosis. Spine Deformity, 7(4), 553-558.
Rohayati, Y., Wulandari, S., Sari, K., 2018. Usability Evaluation of Digital Service Company Portal Using Importance Performance Analysis. 6th International Conference on Information and Communication Technology (ICoICT) Usability, 0(c), 49-54.

Salengke, H.H., 2019. Pemerintah Dorong Pengurangan Sampah dari Sumbernya.

Sensuse, D. I., Prayoga, S.H., 2012. Analisis Usability Pada Aplikasi Berbasis Web Dengan Mengadopsi Model Kepuasan Pengguna (User Satisfaction). Jurnal Sistem Informasi, 6(1), 70.

Taherdoost, H., 2017. Understanding of e-service security Variabelons and its effect on quality and intention to use. Information and Computer Security, 25(5), 535-559.

Veldsman, A., Van Greunen, D., 2017. Comparative usability evaluation of a mobile health app. 2017 IST-Africa Week Conference, IST-Africa 2017, $1-8$.

Wei, Q., Chang, Z., Cheng, Q., 2015. Usability study of the mobile library App: an example from Chongqing University. Library Hi Tech, 33(3), 340-355. 